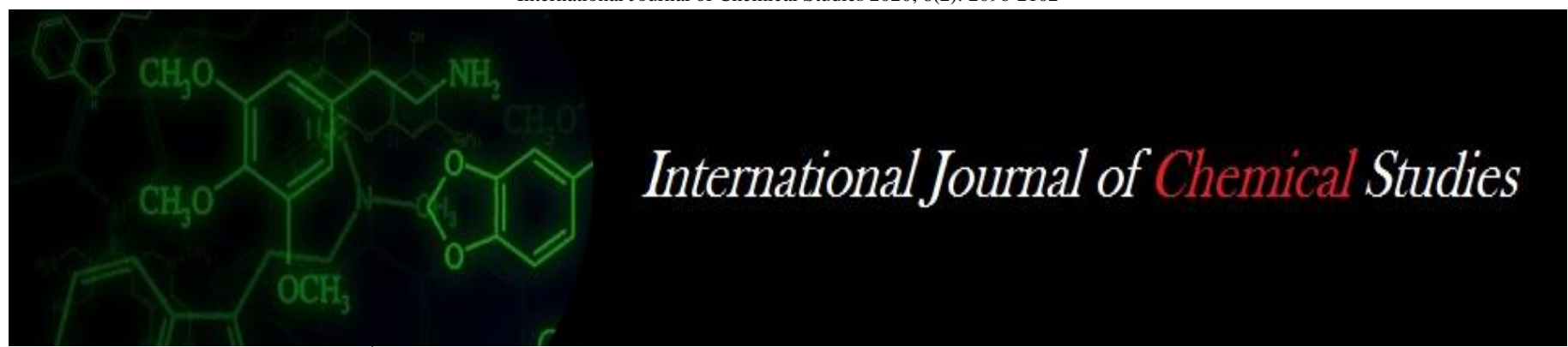

P-ISSN: 2349-8528

E-ISSN: 2321-4902

www.chemijournal.com

IJCS 2020; 8(2): 2096-2102

(C) 2020 IJCS

Received: 01-01-2020

Accepted: 03-02-2020

Suma TC

Assistant Professor, Department

of Crop Physiology, UAS,

Raichur, Karnataka, India

Vivek R Kamat

M.Tech, Department of Farm

Machinery and Power

Engineering, COAE\&T,

CCSHAU, Hisar, Haryana, India

Sangeetha TR

M.Sc, Department of Crop

Physiology, UAS, Raichur,

Karnataka, India

Malla Reddy

Ph.D, Department of Agronomy, UAS, Raichur, Karnataka, India

Corresponding Author:

Vivek R Kamat

M.Tech, Department of Farm

Machinery and Power

Engineering, COAE\&T,

CCSHAU, Hisar, Haryana, India

\section{Review on hydroponics green fodder production: Enhancement of nutrient and water use efficiency}

\author{
Suma TC, Vivek R Kamat, Sangeetha TR and Malla Reddy
}

DOI: https://doi.org/10.22271/chemi.2020.v8.i2af.9060

\begin{abstract}
Fodder crops produced by hydroponics technology are also known as hydroponics fodder, sprouted fodder or sprouted grain. Sprouting of the grains is made inside a greenhouse within a short period of approximately seven days. In India, the increase in the livestock population along with the intensive rearing system has resulted in the increase demands for feeds and fodder. The unavailability of quality green fodder adversely affects the productive and reproductive efficiency of the livestock. Besides the less availability of land, more labour for cultivation (sowing, weeding, harvesting etc.), more time for harvesting, non-availability of same quality around the year, requirement of manure and fertilizer; the uncertainty of rain fall, water scarcity and natural calamities due to climate change are the major constraints for green fodder production encountered by the livestock farmers. Due to the above constraints the hydroponics technology is coming up as an alternative to grow fodder for farm animals. Further, hydroponics technology for fodder production will be very effective for requires 2-3 litres of water to produce one kilogram of green fodder as compared to 55 to 75 litres of water required for the traditional cultivation practices. No wastage of water as the available water is also recycled and utilized. Hydroponic fodder is especially rich in vitamin $\mathrm{C}$ and $\mathrm{E}$ apart from minerals and high protein content. Hydroponic fodder production not only improves nutrient content by using less water and less space but also a cost effective method for a huge demand in supplying fodder for livestock.
\end{abstract}

Keywords: Hydroponics, water-use efficiency, fodder, nutrient and livestock

\section{Introduction}

The word hydroponics comes from the Greek word 'water work.' Hydro implies 'water' and ponic means 'working' and it is a technology of soil-free grain sprouting or increasing crops, but only with water or nutrient-rich solution. However, with the use of fresh water alone, hydroponics fodder can be well produced and the use of nutritionally-rich solution is often not obligatory. Also, the additional costs of the nutrient solution may not justify its use rather than the fresh water, unless the feeding value of the hydroponics fodder is significantly improved owing to the use of nutrient solution. The metabolism of seed nutrient reserves is sufficient to fuel the growth of the fodder plant for a brief period of time. Water used for grain sprouting should be clean and free of chemical agents as the main source of microbial contamination is water.

Hydroponic feed crops are also known as hydroponic forage, sprouted feed or sprouted grain (Dung et al., 2010a) ${ }^{[9]}$. Grain sprouting is done in a greenhouse within a short span of about seven days (Sneath and McIntosh, 2003) ${ }^{[36]}$. A greenhouse is a framed or inflated structure which is covered by a transparent or translucent material in which the crops can be cultivated under circumstances that are at least partially managed and adequately large to permit a person to work within it to carry out cultural operations (Chandra and Gupta, 2003) ${ }^{[6]}$.

\section{Why hydroponics fodder??}

The unavailability of quality green fodder adversely affect the productive and reproductive efficiency of the livestock. In addition to less land availability, more farm labor $\mathrm{ft}$ cultivation (sowing, earthning, weeding, harvesting, etc.), more working time for harvesting, nonavailability of that same quality across the year, manure and fertilizer requirements ; the uncertainty of rainfall, water scarcity as well as natural disasters due to climate change are also the main challenges encountered by livestock farmers for the production of green fodder (Reddy et al., 1988, Naik et al., 2014) ${ }^{[33,21]}$ Because of the above limitations, 
hydroponics technology is emerging as an alternative for farm animals to grow fodder. Moreover, hydroponics technique for the production of fodder will be quite efficient for the rearing of small ruminants (sheep and goats) since these animals require less DM and are shifted from extensive to intensive rearing (Pandey and Pathak, 1991) ${ }^{[32]}$.

Even so, only green fodder cassn can be produced using fresh water. Water sunlight and additional nutrients are the only inputs required to grow green fodder via hydroponic seed as the green fodder is fed to the animals after about 6-8 days of plant growth barley (Reddy et al., 1988) ${ }^{[33]}$, oats, wheat (Snow et al., 2008) ${ }^{[37]}$, sorghum, alfalfa, cowpea (AI-Karaki and AI-Hashimi, 2012) ${ }^{[1]}$ and maize (Naik et al., 2011; Naik et al., 2012a) ${ }^{[29,25]}$ etc., are the important cultivars using hydroponics to produce high quality nutritious green fodder for dairy animals. Sorghum when fed, less than 45 days of growth causes prussic acid (HCN) toxicity so it is not preferred in hydroponic fodder production (Anonymous, 2012; Anonymous, 2013; Naik et al., 2013b) ${ }^{[4,5,27]}$.

It is possible to grow oat, maize, wheat, barley, cow pea, etc. by hydroponics methods (Morgan et al. 1992: Naik, 2012b) $[18,25]$. The choice for hydroponics technology is however regional and agro-climatic situations and easy seed availability. In India, easy seed availability, lowered seed costs, outstanding production of biomass and quickly increasing habit; maize is the assortment of grain for the production of hydroponic fodder. The grain should be hygienic, sound, undamaged or not insect infested, untreated, viable and good quality.

\section{Method of Hydroponics Fodder Production}

Seeds are soaked in normal water for 4-24 hours for the production of hydroponics fodder, based on the type of seeds that are drained and placed in the individual greenhouse trays to grow in the greenhouse. For maize, 4 hours is enough to soak in normal water (Naik et al., 2013b) ${ }^{[27]}$. The seed rate (amount of seeds loaded per unit surface area) often impacts the hydroponic fodder yield, which differs with the seed type. It is possible to produce hydroponic maize fodder with a seed rate of $6.4-7.6 . \mathrm{kg} / \mathrm{m}^{2}$. If seed density becomes large, the root mat has a greater opportunity of microbial contamination, which influences the fodder's growth. The beginning of germination and root visibility differs with the seed type. Maintaining clean and hygiene is very essential in the production of hydroponic fodder as greenhouse is extremely susceptible to microbial contamination, especially owing of mould growth due to high humidity. The grains can usually sprout within the greenhouse for seven days and on the eighth day they are fed to the dairy cattle (Trubey and Otros 1969; Sneath and McIntosh, 2003; Dung et al., 2010a; Molla and Brihan, 2010; Dung et al., 2010b; Fazaeli et al., 2011; Naik, 2012b; Naik, 2013a; Naik, 2013b) [39,36, 9, 16, 10, 25, 26, 27].

\section{Physiological emphasis on green fodder production}

During germination the dry matter content is lost due to increased metabolic activity of seeds. When seeds are sown the solutes leak out of them and the leakage is fastest at the start of imbibition and comes to halts after one day. For photosynthesis it is found that light is not needed for sprouting of cereal grains. If the seedlings are grown without light or at low light intensity, photosynthesis is not nonexistent or minimal and seedling must depend in their starch and fat reserves to meet their energy demands. If the sprouts are stacked inside the shade many sprouts may be heavily shaded. Until end of day 5 it is found that photosynthesis is not mandatory for metabolisms of the seedlings. Barley grain and barley grain processed such as sprouts are extremely digestible, nutritious feed. The energy gain is mainly reliant on starch, and sprouting converts much of the starch into sugars, and sprouting also increases leaf fiber content. Grains and their sprouts both are having high digestible and metabolise energy (Roger and Felicity, 2003).

It is also found that fresh weight of the green fodder is increased 4.5 times of the original seed weight after 6 days of sprouting for barley grain. Water plays effective role on increasing of the weight. No difference of performance of calves are found when green fodder is introduced in the diet and it is also found that the cost of feeding is increased upto $24 \%$ compared to control diet. For economic point of view this fodder is not advised in diet for calves (Fazaeli et al., 2011) ${ }^{[12]}$.

In another study, it is found that significant difference for dry matter content for barley and GF. By increasing the growth periods from 6 to 7 days, the dry matter content of GF is decreased. According to Peer and Lesson the fresh weight is increased from 1.72 times of original seed rate. The percentage of soluble protein is found increased in GF harvested on $7^{\text {th }}$ and $8^{\text {th }}$ day but no changes are found in insoluble protein. During sprouting period of barley visible difference was found in root length and thickness. Average forage yield was obtained $4.93 \mathrm{~kg} / \mathrm{kg}$ of barley on day 6 and $7.21 \mathrm{~kg} / \mathrm{kg}$ of barley on day 8 . Conversion ratio was found 4 to 8 times of seed used for fodder production. It is also concluded that feeding hydroponically grown barley is economically not viable (Fazaeli et al., 2012) ${ }^{[11]}$.

Hydroponic maize fodder weight is noticed to be greater than the seed weight on fresh basis was 5.5 folds. The DM content of the hydroponic maize fodder was slightly high compared to conventional CO-3 green fodder and hydroponic barley fodder. In hydroponic maize fodder the crude protein, ether extract, nitrogen free content found higher and crude fiber, total ash and acid insoluble ash are less when compared to napier bajra hybrid (CO-3) green fodder. There was increase $(\mathrm{P}<0.05)$ in the digestibility of crude protein and crude fiber of the cows due to feeding of hydroponics maize fodder (Naik et al., 2014) ${ }^{[22]}$.

\section{Digestibility/Degradability}

Even if there is a loss in dry matter content of sprouted barley fodder there is being an advantage in their digestibility. In rumen the digestibility of the sprouts is higher than cracked grain. However, comparing the digestibility of shoot and root sprouts, shoots easily degrade in the rumen. Therefore, ruminant animals prefer leafy than stemmy (Dung et al., 2010b) ${ }^{[10]}$.

\section{Energy}

Hydroponic sprouts and processed grains are both nutritious and digestible feeds. Sprouting of grains changes the starch to sugar. On dry matter bases the energy value of sprouts are less than grains with gross energy loss of $2 \%$ (Sneath and Mclntosh, 2003) ${ }^{[36]}$.

\section{Protein}

Research work carried in finger millet straw, maize hydroponic fodder, BHF: barley hydroponic fodder, creep feeds, study was done on the dry matter content, crude fiber content, crude protein content, ether extract and nitrogen free extract. Due to the synthesis of structural carbohydrates such as cellulose and hemicelluloses crude fiber content was found 
higher in finger millet straw. Hydroponic sprouts are noticed to be a significant source of nutrients and comprise an enzyme and grass juice factors that promote rumen microbial growth activity and strengthen livestock effectiveness higher than livestock fed with non-sprout grains. It is also found that daily weight was depressed by $1.17 \mathrm{~g} /$ day due to low crude protein content and difficult for palatable for livestock when they were fed with finger straw millet (Weldegerima et al., 2015). Another research was undertaken to assess hydroponic maize and barley fodder nutritional benefit and importance for Konkan Kanyal goats. They found that sprouting of grains affected the enzyme activities, changes in amino acid profile and increased the total protein which is highly digested by most of the animals. Supplimntation of higher proportion of hydroponically grown maize and barley fodder is having impact on total and daily body weight gain. The body weight is highly influenced to animals when $40 \%$ of hydroponically grown fodder is supplemented with necessary nutrients. The benefit cost ratio is found -0.02 for $100 \%$ finger millet straw, 1.6 for $80 \%$ finger millet straw and $20 \%$ hydroponic maize fodder. 1.5 for $80 \%$ finger millet straw and $20 \%$ hydroponic maize fodder, 2.6 for $60 \%$ finger millet straw and $40 \%$ hydroponic maize \& 2.1 for $60 \%$ finger millet straw and $40 \%$ hydroponic barley\& 2.2 for $60 \%$ finger millet straw, $20 \%$ hydroponic maize and $20 \%$ hydroponic barley (Weldegerima, 2015).

The activity of inactive enzymes of the grains is increased during sprouting, which breakdown reserve chemical constituents that could be used for synthesis of new compounds wile breaking down the nutritionally undesired constituents. Sprout is reported to be a valuable source of antioxidants, chlorophyll, enzymes and alkaline in nature, assisting to boost the productivity of livestock by building a better immune system. In this study DU-3 variety is used and growth period is 15 days. The crude protein content was low on day 1 and was found high on day 8. The ether extract content was highest on day $5 \& 6$. During growth period in hydroponic system the crude fiber and total ash content were increased and the nitrogen free extract found decreased. Acid insoluble ash is not affected during the growth period (Naik $e t$ al., 2016) ${ }^{[23]}$.

An experiment was conducted to find the effect of feeding sprouted maize grains on digestibility of nutrients in heifers. The fodder was grown hydroponically in $25 \mathrm{ft} \times 10 \mathrm{ft} \times 10 \mathrm{ft}$ chamber with $600 \mathrm{~kg}$ daily output with $7.6 \mathrm{~kg} / \mathrm{m}^{2}$ seed rate. Fodder crop is harvested on $8^{\text {th }}$ day and fed to animals. The digestibility is found by feeding hydroponically grown fodder twice with equal amount and clean drinking water is provided for ix days. Hydroponically sprouted grains were palatable and the germinated seeds embedded in the roots are also consumed along with the leaves without wasting any nutrients. The difference in the digestibility of nutrients is due to difference in age or productive stage or quantity of hydroponic fodder fed to animals during experiment (Naik et al., 2016) ${ }^{[23]}$.

Extensive research also made possible to find that dry matter content, crude protein and total ash content are high in kid starter compared to hydroponic fodder but crude fiber, NFE and ether extract content found high in hydroponic maize fodder. It is concluded that feeding of hydroponically maize fodder as partial feed substitute of kid starter on protein basis at $30 \%$ level maintains the growth performance of kids compared to those fed with controlled diet (Shyama et al., 2017).

Animal performance is high dependent on critical element which is protein. Thus there is a need to analyze the feed value of the fodder. In sprouts crude protein, ash and all other minerals except potassium are highly concentrated on a dry matter bases than barley grains. The increase in dry crude protein content is due to loss in dry matter content particularly carbohydrate. Moreover, nutrient absorption also facilitates the metabolism of nitrogenous compounds which lead to increase the crude protein content (Dung et al., 2010b) ${ }^{[10]}$. Nutrient solutions improve the crude protein level of the hydroponic fodder than using tap water (Girma and Gebremarian, 2018).

\section{Hydroponics fodder and increase in water use efficiency}

Hydroponic fodder was grown without any media except water. To produce one $\mathrm{kg}$ of hydroponic fodder 1.62-2 litre of water is needed if water is recycled and 2.5-3.3 litre of water is needed if water is not recycled. The biomass production conversion ratio is affected by quality of seed, overall management, sprinkling frequency, temperature inside the greenhouse, relative humidity and growth period. Large uptake of water initiates increasing metabolic activity of resting seeds leads to complete loss of dry weight (starch) during germinating cycles of hydroponic fodder. It is also concluded that growing of maize fodder hydroponically in a semi-intensive hydroponic unit saves water, labour and shows increase in nutrients such as weight of the fodder, crude protein, ether extract and nitrogen free extract. Hence hydroponic fodder production improves nutrient content with less water, less space used and cost effective (Weldegerima et al., 2015).

For cowpea and barley crops, the green fodder with lush vegetation is produced in 8 days. The green new value is observed high in cowpea, preceded respectively by barley, alfalfa, sorghum and wheat. Compared to many other forage crops, the dry fodder yield of alfalfa is decreased significantly. For seed germination and seedling growth water is basic requirement and it also influences enzyme growth. Hydroponically grown fodder is found enhanced of water use efficiency. Here they found barley and cowpea uses water cost effectively compared to other crops like wheat, sorghum and alfalfa. Water is saved using hydroponic method of fodder production (Ghazi et al., 2012).

Hydroponic technique can be used in a hygienic environment, free of chemicals like those of insecticides, herbicides, fungicides and artificial growth promoters, to produce green fodder for many forage crops. It is a well-known method for producing increased fodder yields, production all year round and less water use. Unlike the field production system that utilizes run-to-waste irrigation methods, recirculation system is being used by the hydroponic fodder system, lowering waste water. Hydroponic fodder production has been noted to require only about 2-3 percent of that water used to produce the same quantity of fodder under field circumstances. Hydroponically produced fodder does have a short growth period of 7-10 days and it does not require a high-quality agricultural land, and only a small piece of land to be needed for fodder production. It is high-quality, protein-rich, fiberrich, vitamin and mineral. In addition to other features, all these unique features of the hydroponic system make it one of the most essential agricultural techniques currently used in many countries, especially in arid and semi-arid areas of the globe. However, determining the best forage crop is crucial in producing the highest yield and quality of fodder as well as, at the same time, considering the economic aspects of the hydroponic production of green fodder by saving seed costs. The objectives of this study were to evaluate seven forage 
crops maize, bajra, fingermillet, foxtailmillet, wheat, cowpea and greengram for green fodder production and water use efficiency under hydroponic conditions. The experiment has been conducted under temperature-controlled conditions $(24 \pm$ $1{ }^{0} \mathrm{C}$ ) and natural window illumination at growth chamber, Department of Crop Physiology, UAS, Raichur. The results showed that green forage can be produced in 10 days from planting to harvest using hydroponic technique. Highest values for green fresh yields were recorded for the crops cowpea, greengram and maize which gave 220, 193 and 217 tons/ha, respectively. Cowpea crop used water more efficiently than the other seven tested crops when produced about $654 \mathrm{~kg}$ fresh matter/m3water in comparison to 633 , $585,552,443,423$ and $376 \mathrm{~kg}$ fresh matter/m3 water for maize, greengram, wheat, bajra, fingermillet and foxtailmilet, respectively. No significant differences between maize and cowpea for water use efficiency were noted. It can be concluded from this study that maize and cowpea crops can be considered as the best choice for production of hydroponic green fodder with less water consumption (Suma et al., 2018in press) ${ }^{[38]}$.

\section{Vitamins}

Hydroponic fodder is specially rich in vitamin C and E. Sprouting improve the vitamin content of the grain. However, the increase in individual vitamins is too small that its practical use in addressing nutritional requirement of cerealbased diets makes little difference on the feed value (Sneath and Mclntosh, 2003) ${ }^{[36]}$.

\section{Minerals}

It is found that seed starts germinating on second day of the sprouting and roots were clearly visible from third and fourth day in hydroponic system. It is also found that the forage mat is reached depend upon the grain from 15 to $30 \mathrm{~cm}$ high. At the $8^{\text {th }}$ day the wheat, barley and oat seedlings were $11.0,14.0$ and 11.5 approx. it is also found that the seed rate has no effect on the proximate constituents of different portions i.e. roots with germinated seeds, leaves and plants of hydroponic maize fodder. Moisture content was high in roots and low in leaves. The crude protein, crude fiber and total ash content (\%) found high in leaves compared to roots and ether extract fond similar in both roots and shoots. It is concluded that seed rate doesn't affect the proximate constituents of different portions (Naik et al., 2017) ${ }^{[24]}$.

In hydroponic fodder, root growth helps for mineral up take which in turn changes the ash and protein contents swiftly from day four on wards (Sneath and Mclntosh, 2003) ${ }^{[36]}$. Absorption also facilitate metabolism of nitrogenous compounds and thus increase the crude protein level. The type of irrigated water for the hydroponic fodder changes the mineral content (Al-Ajmi et al., 2009) ${ }^{[2]}$. However, through the process of chelating sprouting make minerals more available (Shipard 2005) ${ }^{[35]}$.

In a study where the results have suggested that the chicory, as a species is having minimum two inherent patterns of response to zero or low phosphorus conditions. Classical increase in the length of smallest diameter roots in response to $\mathrm{P}$ different conditions is one pattern whereas the second pattern is significant decrease in root tissue density and increased activity under $\mathrm{P}$ conditions. The authors found that there are three groups of roots I chicory each with independent response pattern with $0.28 \mathrm{~mm}$ diameter class, which comprises nearly $90 \%$ of total root length (Richard et al., 2005) ${ }^{[34]}$.

\section{Anti-nutritional factor versus hydroponic feed}

Seed coat and germ of plant seeds has phytic acid. The main effect of this phytic acid is through forming of insoluble with minerals like calcium, iron which cause ineffective absorption in the blood. In an experiment, the animals were provided a diet with high phytic acid and poor in mineral content lead to mineral deficiency symptoms. Sprouting decreases the level of phytic acid. Moreover, enzymes during germination eliminate other detrimental substances. The digestive enzymes in sprouts help as biological catalysts in protein, fat and carbohydrate digestions. Sprouts have hundred times more enzymes than fruits and thus the physiological activity of vitamins, minerals and trace elements depend on enzyme activity. It is indicated that from germination to seven days, it is the period of greatest enzyme activity of the sprouts. If the cereal grains are away of germination, enzymes remain in active due to the inhibitors. These inhibitors avoid seed deterioration for years. However, inhibitors like trypsin inhibitor in soyabeans should be heated, cooked and grinded for inactivation prior to feeding of livestock. Luckily, germination and sprouting also neutralize the inhibitors and enhance the beneficial plant digestive enzymes (Shipard, 2005) $)^{[35]}$.

\section{Effect of hydroponic feed on livestock productivity Milk production}

Studies on improvement of milk production through hydroponic fodder feeding shows improvement than animals fed cereal grains, hay or silage. Hydroponic fodder increase milk yield by $10.07 \%$ in dairy cows (Reddy et al., 1988) ${ }^{[33]}$. Canadian dairy farmers also indicate the increase in feed intake of their cows after feeding of hydroponic fodder and improve their milk yield by $3.6 \mathrm{~kg}$ per day over the lactation period. Moreover, farmers from South Africa reported a drop of 3.6 liters of milk after a leave off of $6.8 \mathrm{~kg}$ fed per day (Mooney, 2005) ${ }^{[17]}$.

\section{Meat production}

Hydroponic fodder improves the body weight fain of lambs. This is realized due to having high bioactive enzymes and ingredients that improve livestock performances (Naik and Singh, 2013) ${ }^{[31]}$. Moreover, the increase in body weight also reflects microbial activity in rumen and enhanced nutrient digestibility (Tudor et al., 2003) ${ }^{[40]}$. In beef cattle average increase of $200 \mathrm{~g}$ is achieved through feeding the hydroponic fodder than maize. Similarly $8 \%$ improvement is reported in birds and other animals (Tudor et al., 2003; Muhammad et al., 2013) ${ }^{[40,16]}$.

\section{Yield, Palatability, Nutritive Value and Digestibility of the Hydroponics Fodder}

Fresh weight raises and the dry matter content reduces during seed sprouting. Fresh yields of $5-6$ folds ( $1 \mathrm{~kg}$ of seed produces $5-6 \mathrm{~kg}$ of fodder) and $11-14 \%$ of dry matter are frequent for hydroponic maize fodder ; moreover, dry matter content of up to $18 \%$ has also been noted (Naik 2013b) ${ }^{[27]}$. Famers of Maharashtra's Satara district reported fresh yield up to 8-10 folds in shade net greenhouse system for hydroponic maize fodder. Many factors influence yield and dry matter content, most often seed type and quality; extent of free water supply prior to weighing; and greenhouse clean and hygienic condition. The fodder acquired from hydroponic techniques looks like a $20-30 \mathrm{~cm}$ hight mat consisting of germinated seeds embedded in white roots and green shoots. The cost of producing new hydroponic maize fodder in Goa condition 
with hi-tech greenhouse is about Rs. 4.-4.50/kg (Naik et al., 2012) ${ }^{[30]}$, in which the seed cost is about 90-98 per cent. Farmers in Maharashtra's Satara district, however, reported that the cost of hydroponics fodder production is very minimal and reasonable in low-cost shade net system with locally grown as well as locally bought seeds.

The fodder of hydroponics is much more nutritious and palatable than the conventional fodder. The nutrient changes during the growth (sprouting) of hydroponics fodder are increase in the crude protein $(\mathrm{CP})$, ether extract $(\mathrm{EE})$, nitrogen free extract (NFE) and decrease in crude fibre (CF), Neutal detergent fibre (NDF), total ash (TA) and insoluble ash (AIA). Fodder is a high quality supplement for livestock diet (Naik et al., 2014) ${ }^{[28]}$.

In addition, there are more potential health numerous benefits for hydroponics fodder. Sprouts are the earth's most enzymerich food and the period of most enzyme activity is typically between germination and age 7-8 days. They are a rich source of antioxidants in the form of $\beta$-carotene, vitamin $\mathrm{C}, \mathrm{E}$ and trace minerals like selenium and $\mathrm{Zn}$. Feeding the sprouted grains strengthens the productivity of the livestock by creating a greater immune system owing to the neutralisation of the acidic condition due to sprouting grains is rich in digestive enzymes and enzyme-rich foods are generally alkaline in nature. Sprouted grains are excellent sources of chlorophyll, xanthophyll-containing pigments and contain a grass juice factor and protein spairing factors that improve livestock production and reproductive performance. In addition to this, it helps to remove anti-nutritional factors such as phytic acid, oxalic acid and other fodder toxicants. Throughout sprouting, moreover, the energy content is reduced as the energy stored in the grain is used and dissipated during the process (Finney, 1982; Cuddeford, 1989; Chavan, 1989; Sneath, 2003; Shipard, 2005) ${ }^{[13,8,7,36,35]}$.

The hydroponics fodders have relished by cattle, horses young growing calve due to softness and palatability. Along with plant shoots, the germinated seeds incorporated in the root system are also eaten, so there is no nutrient waste. The consumption by dairy cows of fresh hydroponic maize fodder may be up to $25 \mathrm{~kg} / \mathrm{animal} /$ day along with a restricted concentration mix and jowar straw Hydroponic fodder supplementation in dairy cow supply improves nutrient digestibility in dairy cows. Milk yield boosts of $7.8 \%$ and 9.3\% (FCM yield) are noted (Reddy, 1988) ${ }^{[33] ; 12.5 \%}$ (Anonymous, 2012) ${ }^{[4]}$ and $13.73 \%$ (Naik, 2013b) ${ }^{[27]}$ due to feeding of hydroponics fodder to lactating cows.

The choice of grain for hydroponics technology, however, relies on geographic and agro-climatic circumstances and seeds being easily available. In India, owing to its easier accessibility, lower price, excellent production of biomass and fast growing habit, maize should be the choice grain for the production of hydroponics fodder. The grain should be clean, sound, undamaged or not insect infested, untreated, viable and good quality.

\section{Advantage of hydroponic techniques of green fodder production}

The green fodder from hydroponics is highly palatable, easily digestive and of better quality as compared to traditional fodder production. In comparison to conventional green fodders, Hydroponics Green Fodder (HGF) contains more crude protein $(13.6 \% \mathrm{v} / \mathrm{s} 10.7 \%)$ and less crude fibre $(14.1 \%$ $\mathrm{v} / \mathrm{s} 25.9 \%$ ) as compared to traditional fodder production.

The fodder is more succulent, palatable, nutritious and intake HGF by livestock is more as compared to CGF and this results in more milk and meat production. Hydroponic techniques require 2-3 litres of water to produce one kilogram of green fodder as compared to 55 to 75 litres of water required for the traditional Cultivation practices. No wastage of water as the available water is also recycled and utilized.

Temperature range of $15-35^{\circ} \mathrm{C}$ and $70-80$ per cent relative humidity $(\mathrm{RH})$ without any fungal growth and technology is economic and environmental friendly. Only $10 \mathrm{~m} \mathrm{X} 5 \mathrm{~m}$ is required to grow $600-650 \mathrm{~kg}$ of fodder per day whereas to produce the same quantity, one hectare of land would be required under traditional cultivation system. 20-25 adult cattle can be reared by this quantity of fodder for one year.

The hydroponics production can easily be measured to cater to the needs of farmers owning just two head of cattle. Under the HGF system, just one labourer can complete the entire process in 2-3 hours per day whereas for same fodder production through tradition system requires more labour to undertake land preparation, sowing, irrigation, cutting, transporting fodder from field to cattle shed, cutting the chaff and finally feeding the cattle. Just 7-8 days is required for HGF when they are about 20 to 30 centimetre in height. The conversion ratio of biomass is as large as 6-7 times that of the 65-80-day CGF. We can produce green fodder in semiprotected circumstances for 365 days a year. Loss is minimal because the whole portion of plant comprising of roots, leaves, grain and stem is fed to the animals. Due to non adding of any nutrient without using soil the green fodder is organically grown. Green fodder production at a faster rate and result in high yield of fodder.

\section{Conclusion}

The production of livestock needs a healthy supply of fodder for better production. But during the summer season there seems to be a lean supply. There must therefore be an alternative like that of the production of hydroponic fodder. The hydroponic system requires a fraction of conventional agriculture's water use while still offering high quality stock feed. In a hygienic surroundings, hydroponic technique can be used for green fodder manufacturing of many forage crops is produced free of chemicals such as insecticides, herbicides, fungicides and artificial growth promoters. In addition to the field production system, which utilizes run-to-waste irrigation practices, the hydroponic fodder system employs recirculation system to avoid waste water. However, high water efficiency is a substantial benefit of this technique, which saves approximately 95-97\% of the water used compared to standard small-scale farming. The production of hydroponic forage needs only about 3-5 percent of the water required to produce the very same quantity of forage produced under field conditions Often seeds of the crops used in the production of hydroponic forage are mostly accessible on the market at a lower price than others, reducing the cost of the production of hydroponic forage.

\section{References}

1. AI-Karaki GN, AI-Hashimi M. Green fodder production and water use efficiency of some forage crops under hydroponic condition. Internl. Schol. Res. Network, 2012.

2. Al Ajmi A, Salih AA, Kadim I, Othman Y. Yield and water use efficiency of barley fodder produced under hydroponic system in GCC countries using tertiary treated sewage effluents. Journal of phytology. 2009; $1: 342-348$ 
3. Al-Karaki GN, Al-Hashimi M. Green fodder production and water use efficiency of some forage crops under hydroponic conditions. ISRN Agronomy, 2011-2012.

4. Anonymous. Moo-ve aside, hydroponics technology is here. The Gomantak Times, 2012.

5. Anonymous. Hydroponics technology benefiting dairy farmers. The Gomantak Times, 2013.

6. Chandra P, Gupta MJ. Cultivation in hi-tech greenhouses for enhanced productivity of natural resources to achieve the objective of precision farming. In: Singh, H.P., Singh, Gorakh, Samuel, J.C., Pathak, R.K. (Eds), Precision Farming in Horticulture, NCPAH, DAC, MOA, PFDC, CISH, 2003, 64-74.

7. Chavan JK, Kadam SS, Beuchat LR. Nutritional improvement of cereals by sprouting. Critical Reviews in Food Science \& Nutrition. 1989; 28(5):401-437.

8. Cuddeford D. Hydroponic grass. In Practice. 1989; 11(5):211-214.

9. Dung DD, Godwin IR, Nolan JV. Nutrient content and in sacco degradation of hydroponic barley sprouts grown using nutrient solution or tap water. J Anim. Vet. Adv. 2010a; 9(18):2432-2436.

10. Dung DD, Godwin IR, Nolan JV. Nutrient content and in sacco digestibility of barley grain and sprouted barley. Journal of Animal Veterinary Advances. 2010b; 9(19):2485-2492.

11. Fazaeli H, Golmohammadi HA, Tabatabayee SN, Asghari-Tabrizi M. Productivity and nutritive value of barley green fodder yield in hydroponic system. World Applied Sciences Journal. 2012; 16(4):531-539.

12. Fazaeli H, Golmohammadi HA, Shoayee AA, Montajebi N, Mosharraf SH. Performance of feedlot calves fed hydroponics fodder barley. J Agric. Sci. 2011; 13:367375.

13. Finney PL. Effect of germination on cereal and legume nutrient changes and food or feed value. A Compressive review. Recent Advances in Phytochemistry. 1982; 17:229-305.

14. Gebremedhin WK. Nutritional benefit and economic value of feeding hydroponically grown maize and barley fodder for Konkan Kanyal goats. IOSR J Agric. Vet. Sci. 2015; 8:24-30.

15. Kide W, Desai B, Dhekale J. Feeding Effects of Maize and Barley Hydroponic Fodder on Dry Matter intake, Nutrient Digestibility and Body Weight Gain of Konkan Kanyal Goats. Life Sciences International Research Journal, 2015. ISSN, 2347-8691

16. Molla A, Birhan D. Competition and resource utilization in mixed cropping of barley and durum wheat under different moisture stress levels. World J Agric. Sci. 2010; 6(6):713-719.

17. Mooney J. Growing cattle feed hydroponically. Meat and livestock Australia, 2005, 30.

18. Morgan J, Hunter RR, O'Haire R. Limiting factors in hydroponic barley grass production. In: Proc. 8th International Congress on Soilless Culture. Hunter's Rest, South Africa, 1992, 241-261.

19. Muhammad S, Afzal H, Mudassar S. Use of sprouted grains in the diets of poultry and ruminants. Pakistan Indian Research Journal. 2013; 2(10):20-27.

20. Naik PK, Singh NP. Hydroponics fodder production: an alternative technology for sustainable livestock production against impeding climate change. In compendium of model training course 'Management Strategies for Sustainable Livestock Production against impending climate change', held during November 1825, Southern Regional Station, National Dairy Research Institute, Adugodi, Bengaluru, India, 2013, 70-75.

21. Naik PK, Dhuri RB, Karunakaran M, Swain BK, Singh NP. Effect of feeding hydroponics maize fodder on digestibility of nutrients and milk production in lactating cows. Indian Journal of Animal Science. 2014; 84(8):880-883.

22. Naik PK, Dhuri RB, Karunakaran M, Swain BK, Singh NP. Effect of feeding hydroponics maize fodder on digestibility of nutrients and milk production in lactating cows. Indian Journal of Animal Science, 2014; 84(8):880-883.

23. Naik PK, Karunakaran M, Chakurkar EB, Swain BK, Singh NP. Digestibility of nutrients in crossbred heifers supplemented with hydroponically sprouted maize grains. Indian Journal of Animal Sciences. 2016; 86(10):12101212.

24. Naik PK, Swain BK, Chakurkar EB, Singh NP. Effect of seed rate on yield and proximate constituents of different parts of hydroponics maize fodder. 2017; 87:109-112.

25. Naik PK. Effect of soaking time on yield of hydroponics maize fodder. (Un-published), 2012b.

26. Naik PK. Effect of seed rate on the yield of hydroponics maize fodder. (Un-published), 2013a.

27. Naik PK. Yield and dry matter content of hydroponics maize fodder (Un-published), $2013 \mathrm{~b}$.

28. Naik PK. Hydroponics green fodder for dairy animals. In: Recent Advances in Animal Nutrition (M.P.S. Bakshi and M. Wadhwa; Eds). Satish Serial publishing House, 403, Express Tower, Commercial Complex, Azadpur, Delhi110 033, India, 2014.

29. Naik PK, Dhuri RB, Singh NP. Technology for production and feeding of hydroponics green fodder. Extension Folder No. 45/ 2011, ICAR Research Complex for Goa, Goa, 2011.

30. Naik PK, Dhuri RB, Swain BK, Singh NP. Cost of production of hydroponics fodder maize. In: Proceedings of 8th Biennial Animal Nutrition Association Conference on 'Animal Nutrition Research Strategies for Food Security', Bikaner, Rajasthan, India, 2012, 12.

31. Naik PK, Dhuri RB, Swain BK, Singh NP. Water management for green fodder production as livestock feed in Goa. In: Abstracts of International Conference on 'Water Management for Climate Resilient Agriculture' held at Jalgaon, Maharashtra, India, 2013, 28-31, 2012, 126-127.

32. Pandey HN, Pathak NN. Nutritional evaluation of artificially grown barley fodder in lactating crossbred cows. Indian J Anim. Nutr. 1991; 8(1):77-78.

33. Reddy GVN, Reddy MR, Reddy KK. Nutrient utilization by milch cattle fed on rations containing artificially grown fodder. Indian J Anim. Nutr. 1988; 5(1):19-22.

34. Richard WZ, Ghiath A, Alloush, David P, Belesky. Differential root morphology response to no versus high phosphorus, in three hydroponically grown forage chicory cultivars. Environmental and Experimental Botany. 2006; 57:201-208.

35. Shipard I. How Can I Grow and Use Sprouts as Living Food. Stewart Publishing, 2005.

36. Sneath R, McIntosh F. Review of hydroponic fodder production for beef cattle. Department of Primary Industries: Queensland Australia. 2003; 84:54.

37. Snow AM, Ghaly AE, Snow A. A comparative assessment of hydroponically grown cereal crops for the 
purification of aquaculture waste water and the production of fish feed. Am. J Agric. Biol. Sci. 2008; 3(1):364-378.

38. Suma TC, Mallareddy, Sangeetha TR, Amaregouda A. Green fodder production and water use efficiency of forage crops under hydroponic conditions. Grisaas (Pres), 2018.

39. Trubey CR, Otros Y. Effect of light, culture solution, and growth period on growth and chemical composition of hydroponically produced oat seedlings. Agron. J. 1969; 61:663-665.

40. Tudor G, Darcy T, Smith P, Shallcross F. The intake and live weight change of drought master steers fed hydroponically grown, young sprouted barley fodder, Department of Agriculture Western Australia. Agriculture and Veterinary Science. 2003; 2:24-30. 